\title{
Doing Heritage Together - New Heritage Frontiers in Collaborative Planning
}

Riesto, Svava; Tietjen, Anne

Published in:

Defining Landscape Democracy / Hva betyr landskapsdemokrati?

Publication date:

2015

Citation for published version (APA):

Riesto, S., \& Tietjen, A. (2015). Doing Heritage Together - New Heritage Frontiers in Collaborative Planning. In S. Egoz (Ed.), Defining Landscape Democracy / Hva betyr landskapsdemokrati? (pp. 57-58). Norwegian University of Life Sciences.

https://www.nmbu.no/sites/default/files/pdfattachments/defining_landscape_democracy_proceedings.pdf 


\section{Doing Heritage Together - New Heritage Frontiers in Collaborative Planning}

\section{Svava Riesto and Anne Tietjen}

University of Copenhagen

\section{Keywords: Heritage production; collaborative planning; spatial development; Denmark}

How can cultural heritage contribute to socially sustainable landscape development in democratic societies? This paper explores new heritage frontiers in collaborative spatial planning processes. Throughout the last three decades, heritage management has become increasingly integrated with spatial planning and in particular the transformation of existing built environments and landscapes. In this context, cultural heritage is often not produced to safeguard relics from the past, but rather to contribute to political, social and economic spatial development (Fairclough, 2009). The European Council's Faro Convention from 2005 thus conceives cultural heritage as a malleable resource for sustainable spatial development while emphasising cultural heritage as an essential constituent of place and identity. When seen as an active component in spatial planning, the processes of heritage making and the outcome, the heritage product, often departs substantially from established practices. Heritage is not only selected and managed by historians, restoration architects and other experts, but is rather an issue for debate in democratic processes that involve a broad range of actors. Furthermore, heritage value is not only ascribed to objects that are considered particularly good or representative relics from the past. In a forward-looking perspective, everything that is inherited from the past can potentially have value for spatial development - buildings, cultural traditions and place narratives.

Taking a starting point in the Faro convention, heritage scholar Graham Fairclough defines a number of new 'frontiers' in relation to 'doing heritage' (Fairclough, 2009, p. 31). The integration of heritage management with democratic spatial planning processes requires, first, learning other, collaborative ways of defining or valuing heritage and involving new actors, in particular the affected citizens, local communities and stakeholders. Second, it requires adopting new forward-looking objectives. This implies conceiving heritage products as means rather than ends, and as an active part of development rather than fixed results. Third, it requires adopting new ways of dealing with heritage beyond preservation.

This paper adds to the understanding of heritage, as a product and process, in collaborative spatial planning processes. To this end, we explore two cases from Denmark, a country with a strong tradition for integrating heritage interests with a democratic planning practice. The two cases are innovative examples of making and using heritage in collaborative processes dealing with a prevalent task: the preservation, transformation and development of built environments with strategic goals. In both cases, heritage played a central role as a resource for the development of a large-scale area and as a tool for participation. Case 1, Albertslund Syd, examines the physical and social renewal of a suburban 1960s social housing area. Case 2, The good life at the seaside, studies the strategic development of place-based potential in the shrinking rural municipality of Thisted which resulted in the transformation of piers and landing places in three coastal villages.

Based on these cases, we aim to substantiate new heritage frontiers in collaborative spatial transformation processes. We assume that heritage is not a thing in itself, but is instead formed of cultural processes and products that are continuously re-created according to changing ideas, values and objectives, and influenced by multiple forces. Guided by Tunbridge and Ashworth's process-based model of heritage as a conflicted product made by people (Tunbridge \& Ashworth, 1996) we study how different perceptions of and interests in heritage are negotiated in collaborative spatial planning processes. Concretely, we analyse heritage and planning documents, design proposals and other documentation of the transformation processes in Albertslund Syd (1999-2014) and Thisted (2007-2014). This analysis is supplemented by field visits and interviews with key professionals who contributed to the planning processes.

On the whole, the two cases demonstrate that collaborative heritage making in spatial planning processes has a lot of potential for contributing to socially sustainable landscape development. By including new actors, such as local communities and stakeholders, in what was previously a narrow domain of official heritage experts and managers, such processes can strengthen public dialogue and democratic decision-making in society. By conceiving heritage as a collaborative process and product, and by applying the large-scale perspective from spatial planning, multiple interests can be integrated and negotiated. By doing heritage together, local communities can strengthen their sense of belonging, community and responsibility for their environment. Such positive effects can contribute to the increased social resilience of places that face economic, demographic, and social challenges. 
By applying collective survey methods and future-oriented criteria for selection processes, new heritage values, such as narratives from everyday life and people's living practices, can be identified, preserved and further developed. In this way, heritage can become relevant to people in a perspective that concerns their desired future just as much as their conception of the past. A new and broader conception of possible heritage products that goes way beyond building preservation can contribute to inclusive and socially sustainable spatial development.

Despite the clear potential, however, collective heritage making in planning has limitations and implies new challenges. First, the democratic potential of such processes has a problematic side to it. Unlike in representational democratic processes, where every citizen has a voice, collaborative planning and heritage making only gives voice to those who participate actively in the process. It is therefore important to question how collaborative heritage making can include the perspectives and interests of those who do not take part in the process. The cases show some of the tools that planning professionals are currently developing to deal with this challenge, such as actively seeking out unheard groups or groups that are likely to remain passive.

Secondly, collaborative heritage making can blur decision-making. Explorative processes characterised by dialogue between heritage professionals and local communities can strengthen the relevance and positive effects of heritage making, but they may also potentially blur the power-play behind heritage selection and assemblage. It is therefore important to be aware of and to clearly communicate at which point of the heritage making process the local community is being involved and what the scope of influence is on decision-making. These are often discussed challenges to public participation in spatial planning processes (Agger \& Hoffmann, 2008), from which collaborative heritage making might be able to learn and vice versa.

Finally, relating heritage making so closely to planning objectives and to the present interests of local communities does have limitations. While heritage in spatial planning is a growing field, it does not fully cover all the benefits that heritage can have to societal interests. Notably, heritage making also has potential as an alternative to short-term planning horizons in that it can safeguard physical structures whose value is not recognised by a contemporary public, and which have no immediate development or reuse potential. This apparently 'useless' heritage might be overlooked in collaborative spatial planning processes. Furthermore, a focus on development and transformation potential which lead to increased attention to intangible heritage values and products in the studied cases - might also lead to less attention to the preservation of the physical traces of our culture. Collaborative heritage making in spatial planning thus raises fundamental questions as to why and for whom we wish to preserve and develop heritage in radically new ways.

\section{References}

Agger, A., \& Hoffmann, B. (2008). Borgerne på banen - håndbog til borgerdeltagelse i lokal byudvikling [Citizens to action - handbook for public involvement in local urban development]. Copenhagen: Velfærdsministeriet.

Council Of Europe. (2005). Council of Europe Framework Convention on the Value of Cultural Heritage for Society. Council of Europe Treaty Series - No. 199.

Fairclough, G. (2009). New Heritage Frontiers. Heritage and Beyond. Strasbourg, France: Council of Europe Publishing.

Tunbridge, J.E., \& Ashworth, G.J. (1996). Dissonant Heritage: The Management of the Past as a Resource in Conflict. West Sussex, England: Wiley. 


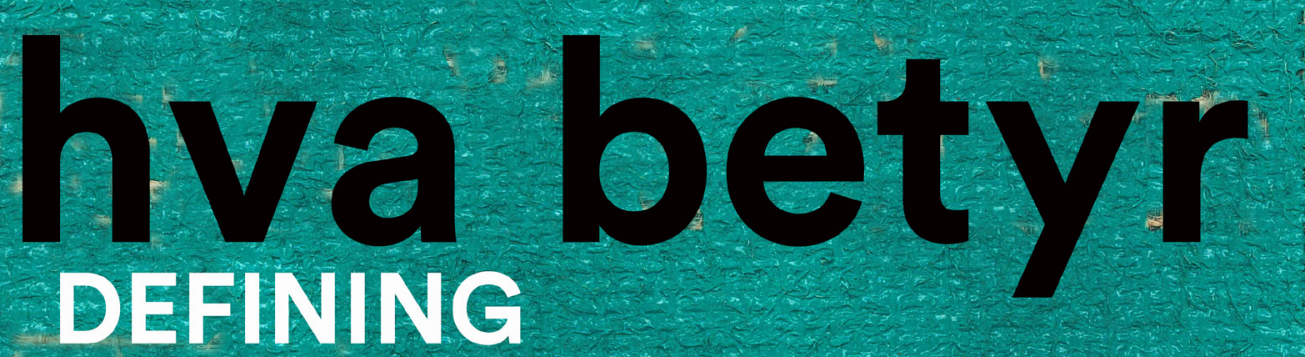

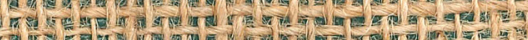
no - IVIa betyr
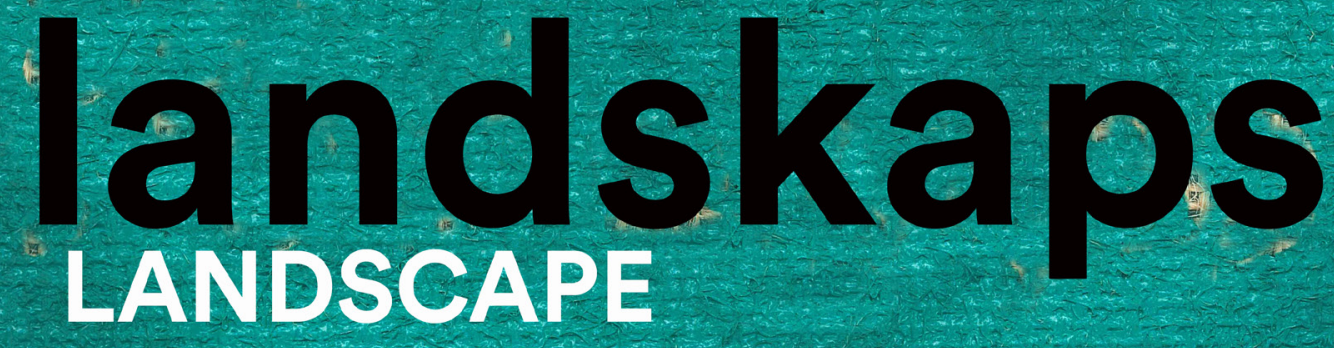

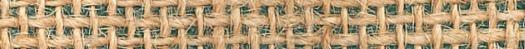

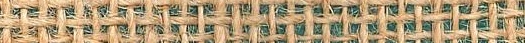

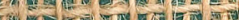

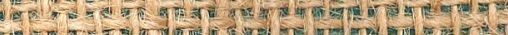

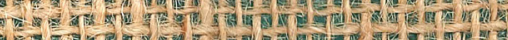

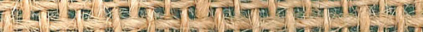
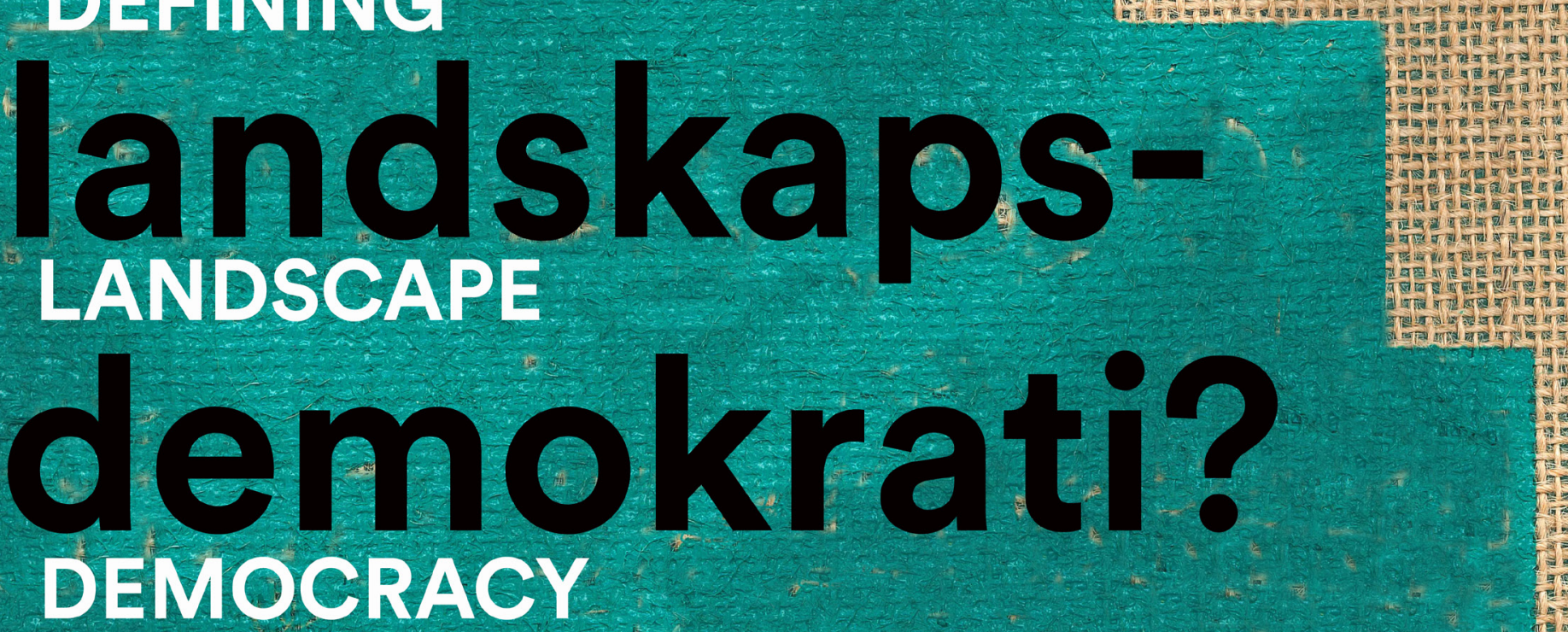

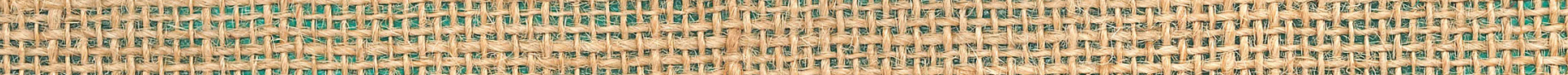

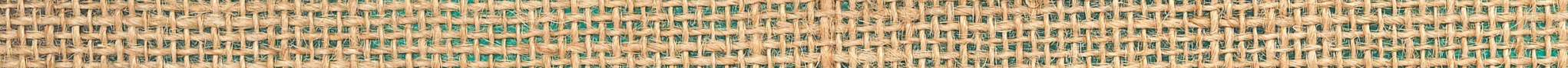

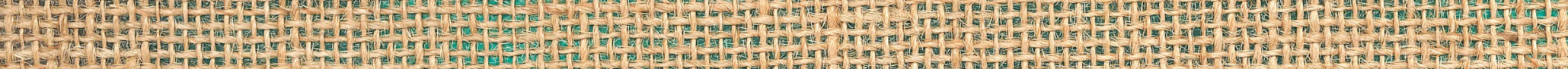

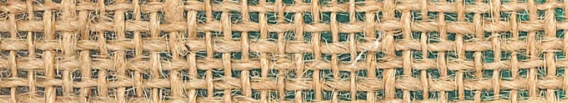

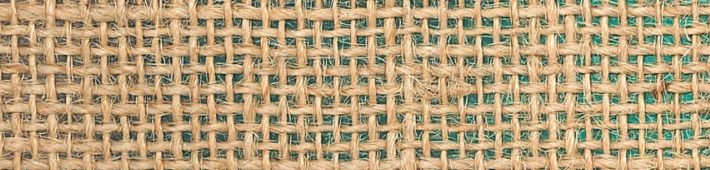

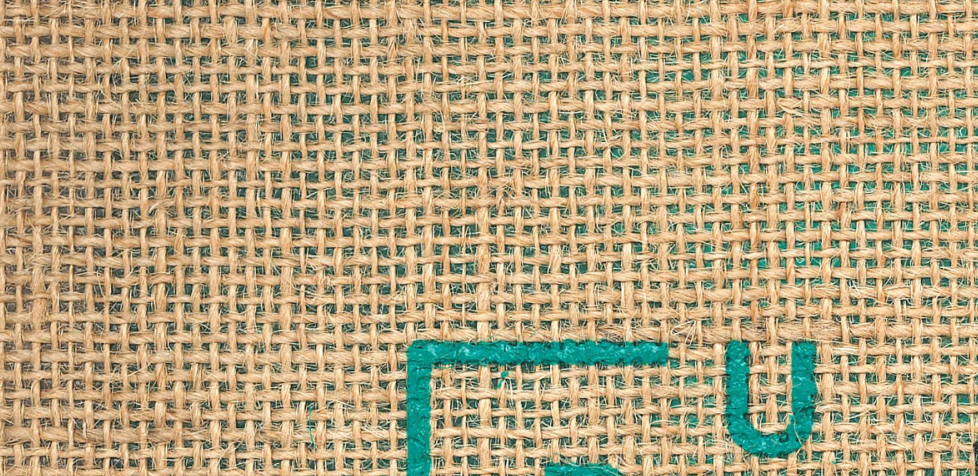

\section{Norges miliz-og} biovitonstapeloo 
Defining Landscape Democracy Conference Reader

Edited by Shelley Egoz

Norwegian University of Life Sciences

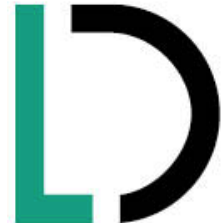

CENTRE FOR

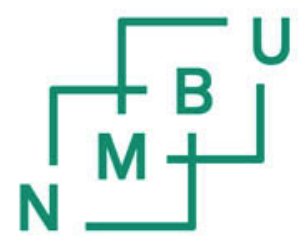

Cover design: Deni Ruggeri

Typesetting: Sofia Lundin

(C) 2015 the Centre for Landscape Democracy (CLaD,) Norwegian University of Life Sciences (NMBU) ISBN 978-82-575-1279-8 